\title{
TRAILING HARRY POTTER INTO ROMANIAN
}

\author{
Ruxandra DRĂGAN \\ University of Bucharest, Romania
}

\begin{abstract}
Characteristic of English and other Germanic languages, Goal of Motion constructions represent a challenge for any translator rendering them into a Romance language. This is because to express the motion of an entity to/towards a Goal in a particular manner, English typically combines a manner-of-motion verb or a verb of sound emission with a dynamic preposition like into in He ran into the park. However, the combination is not generally available in Romanian and other Romance languages, since they not only lack dynamic prepositions, but also have far fewer manner-of-motion verbs. Consequently, to render Goal of Motion into Romanian with as little loss as possible, a translator will have to resort to various translation techniques to compensate not only for the lack of dynamic prepositions in this language, but also for its far poorer class of manner-of-motion verbs. This paper proposes several strategies for the translation of Goal of Motion constructions into Romanian and shows that they depend on the lexical and syntactic resources available in this language. An analysis of the techniques employed in a selected sample from two Romanian translations of the Harry Potter series indicates that the translators' strategies generally mirror Talmy's $(1985,2000)$ typological classification of Germanic and Romance languages into satellite-framed and verb-framed languages, respectively.
\end{abstract}

Keywords: Goal of Motion, Path verbs, Manner verbs, directional PPs

\section{INTRODUCTION}

An unavoidable consequence of the transfer of meaning from a source text to a target text is translation loss (cf. Hervey \& Higgins 1992) and this is particularly obvious when the translation process involves syntactic constructions that do not

LiNGUACULTURE vol. 12 , no. 1, 2021

Published: 15 June 2021

DOI: 10.4773/lincu-2021-1-0194

ISSN (print): 2067-9696 || ISSN (online): 2285-9403 || www.journal.linguaculture.ro 
exist in both languages. This is also the case of Goal of Motion constructions, whose translation from English into Romanian is investigated in the present paper. My aim is twofold: on the one hand, the identification and analysis of the techniques employed by professional translators in rendering Goal of Motion structures in narratives and, on the other hand, the corroboration of my findings with the analysis proposed in Drăgan (2012), which partially relates Goal of Motion constructions in English and Romanian to the lexicalization patterns proposed by Talmy $(1985,2000)$ for the encoding of motion events in Germanic and Romance languages. From a more theoretical perspective, this paper will also provide answers to two questions related to the linguistic expression of motion events in the two languages, specifically, (1) whether the typological differences between English and Romanian have an impact on the strategies employed in the translation of Goal of Motion constructions, and (2) if these translation strategies are determined by the lexicon and the syntactic structures of Romanian. In order to provide answers to these issues, my analysis will focus on two translation samples selected for their dynamic and dramatic narratives built on vivid motion events. In particular, the investigation will concentrate on the Goal of Motion constructions occurring in Chapter 31 (The Battle of Hogwarts) and Chapter 36 (The Flaw in the Plan) from Harry Potter and the Deathly Hallows by J. K. Rowling and their translation by Ioana Iepureanu (Harry Potter și Talismanele Morții, vol. 7, Editura Egmont România, 2013), and by Tatiana Dragomir (Harry Potter și Talismanele Morții, vol. 7, București: Editura Arthur, 2018).

\section{GOAL OF MOTION IN ENGLISH AND ROMANIAN}

Typical of English and Germanic languages in general, Goal of Motion constructions denote the motion of an entity to/towards a goal in a particular manner, the presence of an obligatory Manner component being the reason why Goal of Motion constructions are considered a special subtype of directed motion. They are built on a manner-of-motion verb or a verb of sound emission which combines with either a dynamic preposition like into (whose internal morphological structure mirrors its complex meaning consisting of both Path (to) and Place (in)), or an ambiguous preposition like behind (which can introduce either the goal of motion or the location of a motion event) (cf. Folli \& Ramchand 2005). Consider the sentences in (1):

(1) a. Mary danced into the room.

b. The boat floated behind the reeds.

c. "Mary a dansat în cameră. "Mary danced in the room." 
Example (1a) illustrates a Goal of Motion construction built on the manner-ofmotion verb dance and the PP headed by the dynamic preposition into, and expresses the event of Mary's going into the room by dancing. Notice that the literal translation of this structure in (1c) does not yield the directed motion interpretation, because the Romanian preposition in (in) has an exclusively locative meaning and, as a result, the entire structure denotes located motion (i.e., the dancing event occurs at the location indicated by the PP in cameră (in the room)). On the other hand, example (1b) is attributed an ambiguous interpretation between directed motion/Goal of Motion (the boat gets behind the reeds by floating) and located motion (the boat is behind the reeds, floating around) due to the ambiguous nature of the preposition behind (dynamic vs. locative).

In Drăgan (2012), I showed that to express directed motion in a specific manner, Romanian, like other Romance languages, employs verbs of inherently directed motion combined with locative PPs and Manner Adverbials, which could take the form of gerunds, PPs or AdvPs (see also Mateu 2002, Folli \& Ramchand 2005, Zubizarreta \& Oh 2007 et al. for other Romance languages):

(2) a. Mary danced into the room.

b. Mary a intrat în cameră în pași de dans / dansând.

"Mary went into the room dancing."

In (2) above, the verb of inherently directed motion a intra (go in/enter) combines with the locative PP în cameră (in the room) and a Manner Adverbial that can be either a PP headed by în (in) (în pași de dans, roughly, using dancing steps) or a gerund (dansând/dancing).

Following a detailed investigation of the two classes of motion verbs in Romanian, I proposed that the choice of this lexicalization pattern is influenced by the fact that Romanian has a rich class of verbs of inherently directed motion (Path verbs) and a less well-represented class of verbs of manner of motion (Manner verbs). This claim is partially supported by Coste (2010), who reached a similar conclusion after a thorough analysis of the subclasses of manner-ofmotion verbs in English and Romanian. Coste's contrastive study demonstrated that the semantic field of human locomotion verbs in Romanian is fraught with lexical gaps when compared to that of English; for instance, while the hyperonym jump, which illustrates one of the three motor patterns, alongside walk and run, has seven troponyms/hyponyms in English (bound, hop, leap, leapfrog, skip, somersault, vault), its Romanian correspondent (a sări) has only two (a sălta (bound/leap), a ţopăi (skip)). Overall, while in English there are around 120 Manner verbs, in Romanian there are only 40 items of this kind. 
In addition to this discrepancy between the classes of Path and Manner verbs, in Drăgan (2012), I also pointed out that in Romanian simple prepositions are mostly locative, with the exception of către and spre (towards), which denote direction/potential goal. The purely stative feature of most simple prepositions in Romanian is another factor that prevents this language from adopting the English pattern to express Goal of Motion.

Alternatively, Romanian can express motion to/towards a goal with or without a Manner component by combining a manner-of-motion verb or a verb of inherently directed motion with complex directional PPs in which both PathP and PlaceP are lexicalized by separate prepositions (cf. Drăgan 2012):

(3) a. A coborât până la malul râului.

"He went down to the bank of the river."

b. A alergat până în parc.

"He ran to the park."

Thus, the sentence in ( $3 \mathrm{a})$ is built on a Path verb (a coborî (go down)) and the complex PP până la (până (up) + la $(a t)=$ to), whereas (3b) consists of a Manner verb (run (a alerga)) and the complex PP până în (până $(u p)+\hat{\imath} n($ in $)=$ to), both complex prepositional phrases denoting spatial goals.

Last but not least, some Romanian manner-of-motion verbs that denote translative motion (cf. Cummins 1996), i.e., an entity's movement through space along a single path without any specification of direction, such as a aluneca (slide), a se fofila/a se strecura (sneak), a se rostogoli (roll), a (se) sălta (leap) a sări (jump), a se târî (crawl), etc., can express Goal of Motion in combination with a PP headed by a simple preposition only on condition that the prepositional phrase can be interpreted as a delimiter (cf. Drăgan 2012):

(4) a. Am să pun scara și-am să mă furișez în pod.

"I will put up the ladder and sneak up into the attic."

b. Și sări pe scara vagonului.

"And he jumped onto the carriage step."

Notice that in (4a), the manner verb a se furișa (sneak) is accompanied by the directional PP headed by the simple preposition $\hat{i n}$ (in), which denotes a spatial goal, not merely location (the Subject moves up the ladder and ends up in the attic). Similarly, in (4b), the Manner verb a sări (jump) combines with the directional PP headed by the simple preposition pe (on) interpreted as the endpoint of motion, not the location the Subject was at while jumping in place.

Leaving aside the special syntactic combinations in (3) and (4), the syntactic structure illustrated in (2) represents the typical lexicalization pattern for 
the expression of motion events in Romance languages as suggested by Talmy $(1985,2000)$. The author proposed that Germanic and Romance languages are typologically different with respect to the expression of motion events, in the sense that they employ different categories to lexicalize the main meaning components involved in the expression of motion, i.e., Path and Manner. Thus, as already discussed, in satellite-framed languages like English, the verb lexicalizes the Manner of motion, and the directional PP lexicalizes the Path, whereas in verbframed languages like Romanian, the verb lexicalizes the Path and the Manner component is expressed by means of an adjunct.

It has long been acknowledged in the literature on translation studies that these typological differences proposed by Talmy have considerable impact on the strategies a translator employs to render motion events, particularly in narratives (Slobin 2005, Ibarretxe-Antuñano 2003, Capelle 2012, R. A. Alonso 2018 et al.). Slobin (2005) suggested that speakers of typologically distinct languages will describe the same motion event in ways that are both shaped by the perspectives they have on reality and influenced by the tools (verbs and prepositions) their languages possess for the encoding of motion events. Beavers, Levin \& Tham (2010) make a similar argument regarding the availability of resources and syntactic patterns across languages and their influence on the expression of motion events. Specifically, narratives in satellite-framed languages include much more information concerning the manner of motion than their translated versions in verb-framed languages. The reason for this might have to do with the status of the Manner component in the two categories of languages. Since Manner is expressed as an adjunct in verb-framed languages, hence an extra element, its added presence in translation would lengthen the message and make it more difficult to process (bear in mind that verb-framed languages focus on the path lexicalized by the verb, not on the manner of motion), which is why Manner is typically backgrounded or omitted altogether in translation. In contrast, Manner occupies a prominent place in the expression of motion events in satellite-framed languages precisely because it is conflated in the verb, which is the nucleus of a sentence. In addition, narratives in satellite-framed languages typically include detailed descriptions of the paths of motion illustrated by chains of directional PPs that make up what we will call "complex Paths" and, through combinations of manner verbs and dynamic directional PPs, they focus on the dynamics of motion in their rhetorical style. In contrast, narratives in verb-framed languages include less detailed path descriptions, and, instead, focus more on setting the scene or background for the narrative; presumably, this is because paths in verb-framed languages are expressed by a series of verbs, not of prepositional phrases, since verb-framed languages lack dynamic prepositions as a rule. 
Consequently, verb-framed translators face important challenges in the translation process since they need to accommodate the features of the source language, which is satellite-framed, to the demands of the target languages, which are verb-framed, hence, they have different lexicalization patterns. In particular, they need to strive to capture the abundance and vividness of manner and path descriptions characteristic of satellite-framed narratives while working with a less elaborate manner lexicon and a poorer array of directional prepositions and, also, while trying to avoid unnatural, heavy manner and path details mapped onto separate phrases and clauses.

\section{TRANSLATION STRATEGIES}

In the present section, my analysis focuses on the strategies employed by the two translators of Harry Potter - Ioana Iepureanu and Tatiana Dragomir (henceforth, II and TD, respectively), in rendering Goal of Motion constructions from English into Romanian, as well as the way in which their choices reflect Talmy's lexicalization pattern for the expression of motion events in Romanian as a verbframed language.

\subsection{Translating manner}

The main strategy employed in the translation of Goal of Motion constructions is grammatical transposition (cf. Hervey \& Higgins 1992). This technique usually involves the replacement of some grammatical structure in the source text, the Goal of Motion construction here, with another in the target text, in this case the syntactic structure identified as the lexicalization pattern typical of Romance languages. This happens because "in translation, grammar often has the effect of a straitjacket, forcing the translator along a certain course, which may or may not follow that of the source text as closely as the translator would like it to." (Baker 95). As mentioned before, this means that, in Romanian, the Path of motion is expressed by a verb of inherently directed motion in combination with a mainly locative, or, infrequently, directional prepositional phrase, while the Manner component is expressed by an adjunct - a gerund, a PP or and AdvP, as illustrated by the italicized syntactic structures in (5) to (10) below:

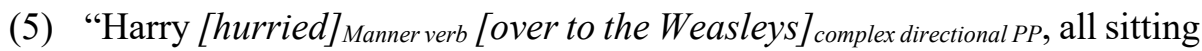
together at the Gryffindor table."

"Harry [se duse] $]_{\text {Path verb [repede] Manner adjunct - AdvP [la membrii familiei }}$ Weasley] locative $P P$, care stăteau cu toții la masa Cercetașilor." (II)

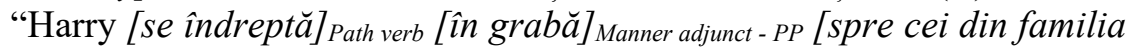
Weasley] directional PP, toți aflați la masa casei Gryffindor." (TD) 
(6) '"Potter' said Professor McGonagall, [hurrying] Manner verb [up to him] $]_{\text {complex }}$ directional PP..."

“- Potter, spuse profesoara McGonagall, [venind] Path verb [grăbită] Manner adjunct - Predicative adjunct [înspre el] complex directional PP,..." (II)

“- Potter, spuse profesoara McGonagall, [apropiindu-se]Path verb [de

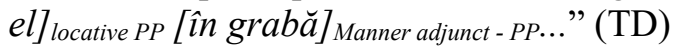

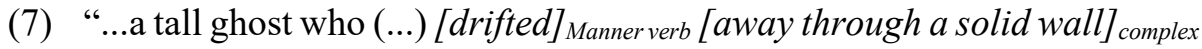
directional PP."

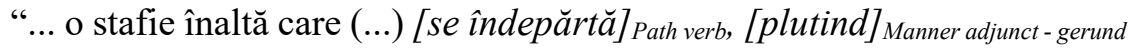
[direct printr-un perete] complex directional PP. ” (II)

“... o fantomă înaltă care (...) [dispăru $]_{\text {change of state verb }}[\text { plutind }]_{\text {Manner adjunct - }}$ gerund [printr-un zid gros] complex directional PP." (TD)

(8) “... a great cavalcade of transparent figures [galloped] $]_{\text {Manner verb }}$ [past them $]_{\text {directional } P P}$ on horses..."

“... o cavalcadă de siluete transparente $[\text { trecu }]_{\text {Path verb }}[\hat{i n} \text { galop }]_{\text {Manner adjunct }}$ $-P P$ [pe lângă ei] complex directional PP...” (II)


grup de siluete transparente călare..." (TD)

(9) “... Hagrid [stumbled $]_{\text {Manner verb }}[\text { forward }]_{\text {directional AdvP }}$, forcing his way through the close-growing trees, back through the forest."

“... Hagrid [înaintă] Path verb, [poticnindu-se] Manner adjunct - gerund, croindu-și drum printre copacii care creșteau la mică distanță unii de alții, spre marginea pădurii.” (II)

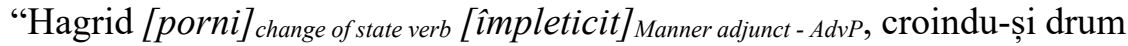
înapoi printre copacii deși din pădure.” (TD)

(10) “... and the snake's body [thudded] Manner verb - sound emission verb [to the ground] directional PP [at his feet] locative PP..."

“... și corpul şarpelui [căzu $]_{\text {Path verb }}[\text { bufnind }]_{\text {Manner adjunct }- \text { gerund }}[$ la picioarele sale] locative PP." (II)

“... iar trupul șarpelui [se prăvăli $]_{\text {Path verb }}[\text { cu o bufnitură }]_{\text {Manner adjunct -PP }}[$ la pământ] locative PP, [la picioarele lui] locative PP...” (TD)

Notice that in almost all the examples above, both translators opted for a Path verb in Romanian (a se duce (go to), a se indrepta (head for), a veni (come), a se 
apropia (approach), a se îndepărta (go away), a trece (pass), a înainta (advance), etc.) in place of a manner verb in English, which they combine with different types of adjuncts. Exceptions to the rule occur in examples (7) and (9), in which the translator (TD) uses change of state (non-motion) verbs. Thus, in (5), for instance, the manner of motion verb hurry is replaced by a se duce (go to) / a se indrepta (head for), while the Manner component is captured by the AdvP repede (quickly) or the prepositional phrase functioning as a Manner Adverbial în grabă (in a hurry). In addition, notice that the strategy of grammatical transposition operates concomitantly with the technique of compensation in place, which generally allows one to make up for translation loss by replicating a certain effect in a different place in the target text (cf. Hervey \& Higgins 1992); in this case, the manner component occurs separately in the syntactic structure, sometimes at its edge (see (6) - “...[apropiindu-se $]_{\text {Path verb }}\left[\right.$ de el] locative PP $[\hat{i n n ~ g r a b a ̆ ~}]_{\text {Manner adjunct - }}$ $P P \ldots$..".

Another translation technique intended to eliminate translation loss is compensation by splitting, whereby the meaning of a single item in the source text is rendered by a complex phrase or a collocation in the target text (cf. Hervey \& Higgins 1992). Interestingly enough, this appears to be a frequent mechanism in Romanian, a language in which the translator has access to a well-represented class of collocations built on light verbs (a face (do), a lua (take), a da (give), etc.), to idioms like a fugi mâncând pământul (bolt/run/fly for your life) or the idiom in (14) - a alerga de îți sfârâie călcâiele (pelt; run as fast as your legs will carry you; run like a deer/a rabbit), and even reduplicatives (a năvăli valurivaluri (storm; rush/barge in waves) in (17)):

(11) "But he broke off as Kingsley had stepped forward on the raised platform to address those who had remained behind."

"Dar se întrerupse când Kinsley făcu un pas înainte pe platforma ridicată, pentru a li se adresa celor care rămăseseră în urmă." (II)

(12) "He leapt up from the plinth and tore back the way he had come, now in pursuit of his one last hope."

"Sări de pe soclu și o luă la fugă, înapoi de unde venise, în căutarea ultimei sale speranțe." (II)

"Sări de pe soclu drept în picioare și o zbughi înapoi pe unde venise, de data aceasta cu o ultimă speranţă." (TD)

(13) "He began edging slowly backward toward the place where the Horcrux sat lopsided upon the bust."

"Începu să se dea încet înapoi spre locul unde Horcruxul era așezat strâmb, pe capul bustului." (II) 
“Începu să se tragă încetișor înapoi, spre locul în care se afla Horcruxul, așezat într-o rână pe capul bustului de piatră." (TD)

(14) "... Harry, Ron, and Hermione pelted along in his wake, and the fire pursued them."

"În spatele lui, Harry, Ron și Hermione alergau și ei de le sfârâiau călcâiele, urmăriţi de foc.” (TD)

(15) "'He was killed while trying to sneak out of the castle grounds,' said Voldemort..."

“- A fost ucis în timp ce încerca să o șteargă din perimetrul castelului, minți Voldemort..." (TD)

(16) "The centaurs Bane, Ronan and Magorian burst into the hall with a great clatter of hooves, as behind Harry the door that led to the kitchens was blasted off its hinges."

"Centaurii Bane, Ronan și Magorian dădură și ei buzna în holul mare de la intrare, tropăind grozav din copite; totodată, în spatele lui Harry sări din balamale ușa care dădea spre bucătării." (TD)

(17) "And now there were more, even more people storming up the front steps..."

"Apoi apărură alți și alți oameni, năvălind valuri-valuri în sus, pe scările de la intrare." (TD)

Thus, in many of the examples above single-item Manner verbs in English were replaced by collocations built on the light verbs a da (give) - (edge backward ( $a$ se da inapoi), burst (a da buzna)), a lua (take) - (tear (a o lua la fugă)), a face (do) - (step (a face un pas)), as well as by idioms like a o zbughi (tear) or sneak out (a o șterge).

In exceptional cases, Goal of Motion can be rendered into Romanian by means of literal translation. In Section 2, I mentioned that, contrary to general belief, there is a small subclass of manner-of-motion verbs in Romanian that may participate in the derivation of Goal of Motion by simply combining with a prepositional phrase headed by a simple (though locative) preposition. These structures are grammatical as long as the verbs in question are [+ translative], i.e., they denote the displacement of an entity along a single path without specifying the goal or direction of motion, and the prepositional phrases are semantically interpreted as delimiters. Such cases are illustrated in (18) to (20), where Manner verbs like a țâşni (shoot), a se rostogoli (slide) and a păși (step) combine with 
locative PPs headed by simple prepositions like in (in) and peste (over), which express the endpoint of motion.

(18) "... and through his eyelids, Harry saw bursts of red and silver light shoot into the air in celebration."

“... și Harry văzu printre gene scântei roșii și argintii țaşsnind în sus, în semn de sărbătoare.” (II)

"Pândind printre pleoape, Harry văzu fulgerele roșii și argintii țâş̧nind în văzduh în semn de victorie." (TD)

(19) "Tears were sliding down from behind the half-moon spectacles into the long silver beard..."

"Din spatele ochelarilor sub formă de semilună, lacrimile i se rostogoleau in barba lungă, argintie..." (TD)

(20) "They clambered over him and onto the spiral stone staircase that moved slowly upward like an escalator."

"Pășiră peste el și urcară scara în spirală, care se mișca încet în sus, ca un lift." (II)

"Cei trei pășiră peste gargui și urcară pe scara din piatră în spirală, care porni ușor în sus ca un lift.” (TD)

Last but not least, translation loss does occur in a fair number of cases where the translators choose to omit the Manner information altogether, but, as already suggested, this happens because speakers of verb-framed languages do not consider the Manner component essential for the expression of motion events, focusing instead on the path of motion lexicalized by the nucleus of the sentence - the verb. Examples of omission are illustrated below:

(21) The sound of hundreds of people marching toward the Room of Requirement grew louder and louder as he returned to the marble stairs. II: Pe măsură ce cobora scara din marmură, zgomotul tuturor celor care se îndreptau spre Camera Necesității devenea din ce în ce mai puternic. TD: Pe măsură ce se apropia de scara de marmură, tropăitul pașilor celor câteva sute de elevi care se indreptau spre Camera Trebuinței se auzea tot mai puternic.

(22) "The two stone gargoyles that usually guarded the entrance to the staffroom had been smashed apart by a jinx that had sailed through another broken window." 
"Cei doi gargui din piatră care păzeau de obicei intrarea în cancelarie fuseseră distruși de un blestem care intrase pe o altă fereastră spartă.”(II)

(23) "Harry hurtled around a corner and found Fred and a small knot of students..."

"Harry coti la capătul holului și dădu peste Fred și un mic grup de elevi..." (II)

(24) "A jet of scarlet light shot past Harry by inches..."

"Un jet de lumină roșie trecu la câțiva centimetri de Harry..., ,(II)

"Un jet de lumină stacojie trecu chiar pe lângă Harry..." (TD)

(25) "... as Malfoy clambered up behind Harry."

“... în timp ce Reacredință se urcă în spatele lui Harry.” (II)

(26) "...a number of older Ravenclaws remained seated while their fellows filed out..."

“...dar câtiva dintre elevii mai mari de la Ravenclaw (...) rămăseseră pe loc când colegii lor ieşiră...” (TD)

Thus, Manner verbs in English are replaced by Path verbs which reflect the directional meanings of the prepositions heading the Path-denoting PPs in the English Goal of Motion constructions. For instance, the manner-of-motion verb march in (21) is replaced by the verb of inherently directed motion a se indrepta (head for), which is semantically related to the English preposition toward, but the Manner component lexicalized by march (i.e., walk as soldiers do, with regular steps of equal length; walk purposefully and determinedly) is not retrieved anywhere else in the translation. Similarly, sail through in (22) is reduced to $a$ intra (enter), hurtle around becomes a coti (turn a corner) in (23), shoot past is translated as a trece (pass) in (24), clamber up becomes a se urca (climb) in (25), and file out turns into a ieși (leave, exit) in (26).

Overall, it appears that there are two main strategies employed in the translation of Goal of Motion constructions from English into Romanian. One aims to compensate for the potential translation loss by retrieving the Manner component elsewhere in the sentence; this is the technique of grammatical transposition, doubled by those of compensation in place or compensation by splitting. It is the strategy that mirrors Talmy's lexicalization pattern for the expression of motion events in Romance languages, whereby the verb expresses the Path of motion and an Adverbial/adjunct (hence, an extra element) expresses the Manner of motion. At the opposite pole, there is the strategy that allows for 
the complete omission of the Manner component by virtue of the fact that Manner is not a salient meaning component in Romanian and Romance languages, generally speaking. However, as already pointed out, the classification of English and Romanian into two typologically-distinct languages is not as clear-cut as one might expect. There are exceptional cases in which the Romanian variant of the Goal of Motion construction is an (almost) perfect rendition of the English version and such instances illustrate a different technique - that of literal translation.

\subsection{Translating complex paths}

The frequency of more extended path descriptions in English and other Germanic languages is also due to the fact that, typologically, they are satellite-framed languages, which allows them to string along several directional prepositional phrases into a complex Path structure in the context of a single Manner verb. Thus, one can hurry out of the bedroom, down the stairs, across the entrance hall, out of the front door, past the rose bushes and into the street. However, if one wants to describe the same complex path in Romanian or other Romance languages, the fact that they are verb-framed prevents the derivation of the same syntactic structure. Instead, each path segment has to be replaced by a separate Path verb semantically related to the preposition heading each directional PP in the satelliteframed structure. Specifically, one exits the bedroom, descends the stairs, crosses the entrance hall, exits the house, passes by the rose bushes and goes out into the street, all of the above in a hurry (i.e., ieși din dormitor, cobori scările, traversezi holul, ieși pe ușa de la intrare, treci pe lângă tufele de trandafiri și ieși pe stradă, toate in grabă). It follows from here that the translation strategy employed to render complex paths into Romanian will also be to pick a separate Path verb for each segment and use an adverbial expression for the Manner component. Indeed, this is the pattern used by the two translators even in the context of less complex paths, as ilustrated below:

(27) "He sensed eyes following him as he [ran] Manner verb [out of the Great $\left.H_{\text {Hall }}\right]_{\text {directional } P P}$ again, [into the entrance hall] directional PP still crowded with evacuating students."

"Simți ochi ațintiți asupra lui, în timp ce [fugi $]_{\text {Path/Manner verb [din Marea }}$ Sală $]_{\text {complex directional } P P}$ și [ieși $]_{\text {Path verb }}[\hat{i n h} \text { holul de la intrare }]_{\text {locative } P P, \text { încă }}$ aglomerat din cauza elevilor care erau evacuați." (II)

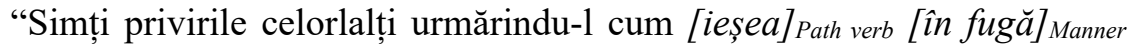

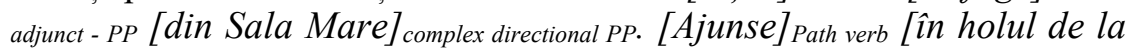
intrare locative PP, încă plin de elevi ce urmau să fie evacuați." (TD) 
(28) “....and Voldemort's would-be victims, Seamus Finnigan and Hannah Abbott, [darted] Manner verb [past him] directional PP [into the Great Hall] directional ${ }_{P P}$, where they joined the fight already flourishing inside it."

“... Seamus Finnigan și Hannah Abbott, care altfel ar fi devenit victimele

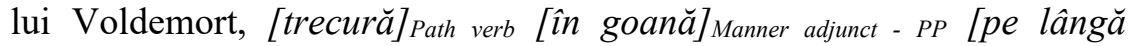

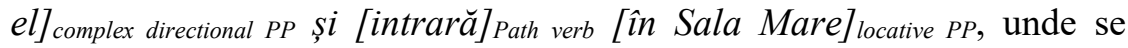
avântară în focul luptei." (TD)

(29) "But it was not over yet: Harry [sped $]_{\text {Manner verb }}$ [between duelers $]_{\text {directional }}$ $P P$, [past struggling prisoners $]_{\text {directional } P P}$, and [into the Great Hall] directional $P P . "$

"Dar încă nu se terminase: Harry [fugi $]_{\text {Path/Manner verb }}[\text { printre dueliști }]_{\text {complex }}$


[intră] Path verb [în Marea Sală $]_{\text {locative PP." (II) }}$

"Dar încă nu se sfârșise. Harry [se avântă] $]_{\text {Path/Manner verb [printre }}$ dueliști $\left.]_{\text {complex directional PP, }[\text { trecu }}\right]_{\text {Path verb }}[p \text { e lângă prizonierii }]_{\text {complex directional }}$ ${ }_{P P}$ care se zbăteau să se elibereze și [ajunse] Path verb [în Sala Mare] locative $P P . "$ (TD)

(30) "They [clambered] Manner verb [over him] directional PP and [onto the spiral stone staircase] directional PP that moved slowly upward like an escalator."

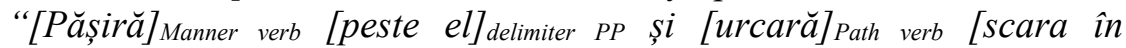
spirală $]_{\text {Direct Object -distance classifier, }}$, care se mișca încet în sus, ca un lift." (II)

"Cei trei [pășiră $\left.]_{\text {Manner verb }[p e s t e ~ g a r g u i]}\right]_{\text {locative PP }}$ și [urcarăa $]_{\text {Path verb }}[p e$ scara din piatră în spirală $]_{\text {locative } P P}$, care porni ușor în sus ca un lift." (TD)

All the examples above include Goal of Motion constructions with complex paths consisting of at least two Path segments (except for example (29), which has three). In order to render the constructions into Romanian, both translators use distinct Path verbs for each preposition heading each Path segment. However, the Manner component occurs only once - as an adjunct modifying only the first Path verb, although the Manner component conflated in the verb in the English construction characterizes each segment of the motion event. This means that something is unavoidably lost in translation even when the manner of motion is mentioned in Romanian. Consider, for instance, the Goal of Motion construction in (28), in which the two characters 'darted past him into the Great Hall...', which is to say that they move at great speed both when they go 'past him' and when they go 'into the Great Hall'. In contrast, in the Romanian version, the Manner adverbial corresponding to the Manner verb in English modifies only the first Path verb, $a$ 
trece (pass), but not the second, a intra (go in): "trecură [în goană] Manner adjunct - PP pe lângă el și intrară în Sala Mare".

On the other hand, notice the interesting cases of a fugi (flee, run) in (27, 29) and a se avânta (launch) in (29), both Path verbs with a Manner component which contradict the garden-variety classification of motion verbs into Path verb and Manner verbs (cf. Drăgan 2012). Since their meanings incorporate a Manner component as well, they need only combine with a morphologically-complex directional PP unlike pure Path verbs, which need to be accompanied by a separate Adverbial element denoting Manner (as is the case, for instance, in Tatiana

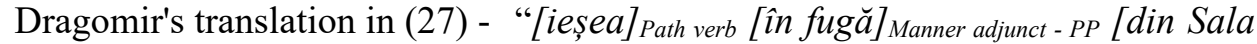
Mare]" - instead of "[fugi] Path/Manner verb [din Marea Sală $]_{\text {complex directional PP", as }}$ proposed by Ioana Iepureanu.

To conclude this section, it appears that the translation of complex paths from English into Romanian is another case of grammatical transposition yielding a syntactic structure that mirrors Talmy's lexicalization pattern for motion events in verb-framed languages. Once again, this renders support to the idea that translation strategies in general are subject to the restrictions imposed by the lexicalization patterns typical of the target language.

\section{CONCLUSIONS}

The present paper has demonstrated that there are several possible strategies to derive Goal of Motion/directed motion constructions and to translate them from English into Romanian, and they are dependent on the typological classification of the source and target languages, as well as on their lexical resources and syntactic rules. Overall, the examples analyzed above indicate that there is, indeed, a main strategy the translators employed when rendering Goal of Motion constructions into Romanian and this strategy mirrors the lexicalization pattern suggested by Talmy $(1985,2000)$ for Romance languages: the Path of motion is rendered by a Path verb, while the Manner of motion is rendered by an adverbial/adjunct. On the other hand, it is equally true that, in many examples, the two translators naturally omitted any Manner descriptions, opting, instead, for the exclusive use of Path verbs. These findings match the conclusions reached by researchers investigating the expression of motion events in other Romance languages, namely, that verb-framed translators pay less attention to the manner of motion and tend to break paths into various segments in accordance with the degree of relevance that they attach to such aspects of experience. In addition, I have shown that the translation strategies adopted for Romanian largely depend on the fact that the translators have access to a fairly rich class of Path verbs, but to a manner lexicon riddled with lexical gaps. What is more, Romanian, like all the other Romance languages, lacks simple prepositions with dynamic 
interpretations, which prevents the free combination of a manner-of-motion verb with a simple PP to express the goal of motion.

\section{Works Cited}

Alonso, Rosa Alonso. "Translating Motion Events into Typologically Distinct Languages." Perspectives 26: 3 (2018), 357-376, DOI: 10.1080/0907676X. 2017.1387578.

Baker, Mona. In Other Words. A Coursebook on Translation, $2^{\text {nd }}$ ed. Routledge, 2011.

Capelle, Bert. "English is less rich in manner-of-motion verbs when translated from French." Across Languages and Cultures 13.2 (2012): 173-195.

Beavers, John, Beth Levin and Shiao Wei Tham. "The Typology of Motion Events Revisited." Journal of Linguistics 46 (2010): 331-377.

Coste, Octavian. "Lexical Gaps and Troponymy. Human Locomotion Verbs in English and Romanian." Romanian Journal of English Studies 7 (2010): 257-265.

Cummins, Sarah. "Movement and Direction in French and English." Toronto Working Papers in Linguistics 15, (1996): 31-54.

Drăgan, Ruxandra. Aspects of Lexical Structure: Verbs in Locative Constructions in English and Romanian. Editura Universității din București, 2012.

Folli, Rafaella and Gillian Ramchand. "Prepositions and Results in Italian and English: An Analysis from Event Decomposition." Perspectives on Aspect. Eds. Henk Verkuyl, Henriette de Swart and Angeliek van Hout. Dordrecht: Kluwer, 2005. 81-105.

Hervey, Sandor and Ian Higgins. Thinking Translation. A Course in Translation Method: French to English. Routledge, 1992.

Ibarretxe-Antuñano, Iraide. "What translation tells us about motion: A contrastive study of typologically different languages." International Journal of English Studies 3.2 (2003): 153-178.

Mateu, J. Argument structure: Relational construal at the syntax interface. Barcelona: Universitat Autònoma de Barcelona dissertation, 2002.

Rowling, J. K. Harry Potter and the Deathly Hallows. Bloomsbury Publishing Plc. London, 2007.

---. Harry Potter și Talismanele Morții. Vol. 7. Transl. Ioana Iepureanu. Editura Egmont România, 2013.

---. Harry Potter și Talismanele Morții. Vol. 7. Transl. Tatiana Dragomir. București: Editura Arthur, 2018.

Slobin, Dan I. " "Relating Narrative Events in Translation." Perspectives on language and language development: Essays in honour of Ruth A. Berman. Eds. R. Dorit Diskin \& H. Bat-Zeev Shyldkrot. Dordrecht: Kluwer, 2005. 115-129.

Talmy, Leonard. "Lexicalization patterns: Semantic structure in lexical forms." Language typology and syntactic description 3: Grammatical categories and the lexicon. Ed. Timothy Shopen. New York: Cambridge University Press, 1985. 57-149. 
Talmy, Leonard. Toward a cognitive semantics, Volume 2: Typology and Process in Concept Structuring. Cambridge, MA: MIT Press, 2000.

Zubizarreta, Maria Luiza and Eunjeong Oh. On the Syntactic Composition of Manner and Motion. Cambridge, MA: MIT Press, 2007.

\section{BIONOTE}

RUXANDRA DRĂGAN is Associate Professor in the Department of English at the University of Bucharest, as well as a Fulbright scholar with a fellowship at the University of Connecticut, where she conducted research on Hate Speech against African Americans in the American Media. She received her Ph.D. in Philology, summa cum laude, from University of Bucharest in 2011. Her doctoral thesis - Aspects of Lexical Structure: Verbs in Locative Constructions in English and Romanian - was published by Bucharest University Press in 2012. In 2016 she also published Modern Approaches to the Derivation of English Resultative Constructions (Editura Printech). Her theoretical research focuses on the lexicon, specifically, the linguistic representation of change of location/state structures at word level (denominal/deadjectival verbs) and sentence-level (resultatives and Goal of Motion constructions). She is currently conducting research in the field of translation studies, focusing on the translation of Goal of Motion and resultatives into Romanian.

Email: ruxandra.dragan@1ls.unibuc.ro 